\title{
Pengaplikasian Web Pada Pendaftaran Siswa Baru Menggunakan Model Waterfall Pada Bimbel Cerdas Ceria
}

\author{
Tri Santoso \\ Program Studi Sistem Informasi \\ STMIK Nusa Mandiri jakarta \\ Jl. Kramat Raya no 16 \\ tri.tos@bsi.ac.id
}

\begin{abstract}
Didalam dunia pendidikan, selalu ada peningkatan yang harus dilakukan. Peningkatan tersebut tidak hanya dari segi ilmu pengetahuan saja, namun dari berbagai sisi yang menunjang dunia pendidikan tersebut. Setiap instansi pendidikan berlomba-lomba melakukan hal tersebut untuk meningkatkan kualitas dalam memberikan pendidikan kepada siswa-siswinya. Dalam tulisan ini, penulis mengambil studi kasus pada Bimbel Cerdas Ceria Tangerang. Sistem pendaftaran pada Bimbel Cerdas Ceria masih menggunakan sistem yang manual. Sistem tersebut mengharuskan calon siswa untuk datang langsung dan melakukan proses pendaftaran. Maka dari itu, dibutuhkan pengaplikasian web pendaftaran siswa baru yang mampu mengatasi masalah tersebut. Pengaplikasian web tersebut dibuat menggunakan metode Waterfall untuk tahapan analisisnya. Dengan adanya pengaplikasian web tersebut, calon siswa tidak perlu datang langsung untuk melakukan pendaftaran. Konfirmasi pandaftaran dapat menggunakan email sehingga tidak sembarang orang yang dapat mengkonfirmasi pendaftaran tersebut. Pembayaran juga menggunakan atm sehingga orang tua siswa tidak perlu datang ke langsung hanya untuk melakukan pembayaran.
\end{abstract}

Keyword: Bimbel, Pembayaran, Pendaftaran.

\section{Introduction}

Manusia merupakan makhluk yang tersempurna di bumi ini. Hampir semua kegiatan yang dilakukan manusia merupakan kegiatan yang terkait dengan kepentingan manusia itu sendiri di dunia ini. Dengan alasan tersebut, kemudian manusia mulai berfikir dan membuat segala sesuatu untuk mempermudah segala kegiatan demi tercapainya tujuan yang telah ditentukan. Seiring berjalannya waktu, berbagai kemajuan dari berbagai bidang telah terjadi sebagai hasil dari sebuah pemikiran.

. Salah satu kemajuan yang jelas terlihat adalah kemajuan dibidang tekhnologi komputerisasi. Saat ini hampir semua bidang telah terkait dengan takhnologi komputerisasi sebagai alternatif keefisiensian dan keefektifan yang memang telah memanjakan dan menghipnotis banyak manusia.

Dalam hal ini, dunia pendidikan juga terkena pengaruah dari pesatnya kemajuan tekhnologi komputerisasi tersebut. Tidak hanya lembaga perkuliah saja, SMA, SMP maupun SD pun sudah menggalakan perubahan besar dalam bidang tekhnologi komputerisasi tersebut. Tak lepas dari itu, lembaga pendidikan lain pun menyusul, salah satunya adalah lembaga pendidikan bimbel atau bimbingan belajar.

Kemajuan dunia pendidikan semakin pesat dengan adanya andil dari kemajuan tekhnologi informasi, berbagai lembaga yang berkecimpung di bidang tersebut berlomba meningkatkan dan memperbaharui kualitas kependidikannya untuk tetap bisa bertahan dan menjadi yang terdepan di bidangnya. Begitu pula yang terjadi pada lembaga pendidikan bimbel yang juga berlomba-lomba meningkatkan kualitas para staff-staffnya dalam pengajaran dan juga ilmu pengetahuan. Namun tak lepas dari itu semua, lembaga pendidikan bimbel juga berusaha meningkatkan kualitas dalam bidang management system dan pengolahan data untuk menunjang kemajuan dalam pelayanannya.

Dari berbagai lembaga pendidikan yang ada, salah satunya adalah Bimbel Cerdas Ceria yang berusaha meningkatkan kualitas pelayannya. Bimbel Cerdas Ceria merupakan salah satu bimbel yang sedang berkembang pesat sehingga sudah mendirikan beberapa cabang, Namun Bimbel Cerdas Ceria masih menggunakan sistem manual [2]. Dimana calon siswa sulit mendapatkan informasi terkait pendaftaran tersebut [7]. Calon siswa juga harus datang langsung untuk melakukan proses pandaftaran [6].

Sistem manual tersebut mengharuskan juga panitia pendaftaran untuk melakukan pengarsipan dengan menggunakan kertas. Hal tersebut dapat menjadi masalah saat pencarian arsip/berkas yang ingin digunakan. 
Pencarian tersebut dapat memakan waktu yang cukup lama, tingkat ketelitian manusia juga menjadi tolak ukur kecepatan proses pencarian tersebut. Selain itu, ada masalah lain yaitu hilangnya suatu berkas/arsip dikarenakan penyimpanan yang tidak baik atau suatu musibah [8].

Tujuan dari tulisan ini adalah untuk mengusulkan pengaplikasian web pendaftaran siswa baru. Dimana pengaplikasian web tersebut dapat mempermudah calon siswa dalam melakukan pendaftaran serta membantu panitia pendaftaran dalam mengelola data pandaftaran tersebut [1].

\section{Research Method}

Penelitian ini memiliki rancangan penelitian sebagai berikut:

a. Problem: Belum adanya pengaplikasian web pendaftaran siswa baru Pada Bimbel Cerdas Ceria

b. Approach: Model Waterfall untuk rancang bangun sistem informasi berbasis web

c. Development: PHP

d. Implementation: Objek penelitian yaitu data pendaftaran siswa baru pada Bimbel Cerdas Ceria

e. Result: Pengaplikasian Web Pendaftaran Siswa Baru

Sumber data penelitian ini berasal dari Bagian pendaftaran siswa baru Bimbel Cerdas Ceria. Teknik pengumpulan data penelitian ini sebagai berikut:

a. Observasi (Observation): Penulis mengumpulkan data dengan melakukan pengamatan langsung pada Bimbel Cerdas Ceria. Penulis mengamati kegiatan pendaftaran yang berlangsung sehingga mendapat data yang diperlukan.

b. Wawancara (interview): Penulis mengumpulkan data dengan melakukan wawancara terhadap panitia pendaftaran pada Bimbel Cerdas Ceria mengenai sistem pendaftaran yang sedang berjalan untuk mendapatkan informasi dan data yang diperlukan.

c. Studi Pustaka (Literarture): Penulis mengumpulkan data dengan melakukan penelitian kepustakaan guna memperoleh aspek-aspek teoritis melalui buku referensi, jurnal ilmiah, dan materi lainnya yang berhubungan dengan proses pendaftaran.

Analisa yang dilakukan penulis berkaitan dengan metode Waterfall yang diterapkan:

a. Pengumpulan data

Data dikumpulkan dengan menggunakan wawancara kepada narasumber secara langsung untuk mengetahui proses sistem yang berjalan dan dokumen-dokumen yang digunakan dalam sistem yang berjalan.

b. Analisis sistem yang berjalan

Proses bisnis sistem yang berjalan digambarkan dengan menggunakan Activity Diagram. Activity diagram menggambarkan workflow (aliran kerja) atau aktivitas dari sebuah sistem atau proses bisnis atau menu yang ada pada perangkat lunak. Kemudian akan dilakukan analisis terhadap dokumen masukan dan keluaran untuk mengetahui kebutuhan sistem usulan.

c. nalisis sistem usulan

Setelah menemukan solusi untuk sistem yang diusulkan untuk mengatasi permasalahan sistem yang berjalan, maka Sistem usulan digambarkan dengan menggunakan use case diagram. Use case diagram merupakan pemodelan untuk kelakuan dari sebuah sistem informasi yang mau dibuat.

d. Desain sistem

Pada tahapan ini akan dilakukan perancangan layar berdasarkan kebutuhan sistem usulan, menggambarkan struktur sistem dari segi pendefinisian kelas-kelas yang akan dibuat untuk membangun sistem digambarkan dengan menggunakan class diagram. Kelas memiliki atribut dan metode atau operasi.

e. Implementasi

Berdasarkan desain sistem yang ada akan diimplementasikan dengan menggunakan bahasa pemrograman php dan basis data MySQL.

f. Pengujian

Aplikasi yang sudah dibuat akan dilakukan pengujian apakah sudah sesuai dengan kebutuhan user atau tidak.[5]

\section{Result and Analysis}

\subsection{Proses Bisnis Sistem}

Bimbel Cerdas Ceria yang merupakan institusi ysng bergerak dalam bidang pendidikan memiliki beberapa kegiatan yang terkait dengan pendaftaran calon siswa hingga pembayaran bulannya. Kegiatankegiatan tersebut akan dijelaskan sebagai berikutnya.

Pada bagian ini penulis menjelaskan sistem berjalan pada Bimbel Cerdas Ceria menggunakan Activity 
Proses diawali dengan administrasi yang memberikan formulir pendaftaran yang akan diisi oleh calon siswa. Calon siswa tersebut mengisi formulir dan melengkapinya dengan berkas-berkas pendukung sebagai persyaratan pendaftaran. Administrasi menerima kembali formulir yang telah diisi beserta-berkas berkas pendukungnya. Selanjutnya calon siswa melakukan pembayaran pendaftaran kepada administrasi. Administrasi memberikan kwitansi pembayaran sebagai tanda telah melakukan pembayaran.

Berikut merupakan bagan diagram yang menjelaskan alur dari kegiatan pendaftaran tersebut.

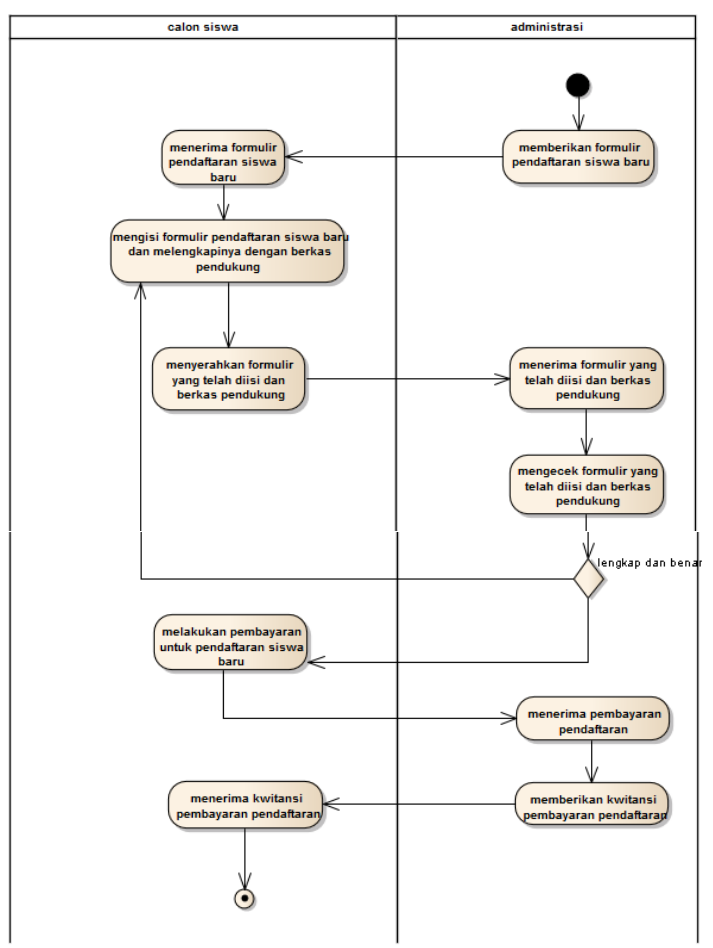

Gambar 1. Activity Diagram Pendaftaran Calon Siswa bimbel.

Selanjutnya akan dibahas mengenai proses kegiatan pembayaran bimbel yang dilakukan siswa

Proses kegiatan diawali dengan siswa yang melakukan pembayaran bimbel. Pemabayaran bimbel terdiri dari dua jenis pembayaran yaitu pembayaran per bulan dan pembayaran per semester. Siswa bisa memilih salah satu dari dua jenis tersebut. Jika telah melakukan pembayaran, administrasi memberikan kwitansi sebagai tanda bukti pembayaran.

Berikut merupakan bagan diagram yang menerangkan alur dari kegiatan pembayaran bimbel tersebut.

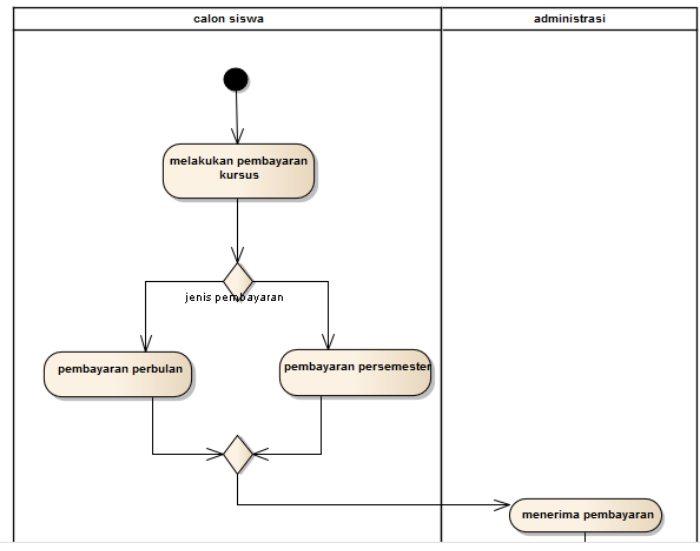




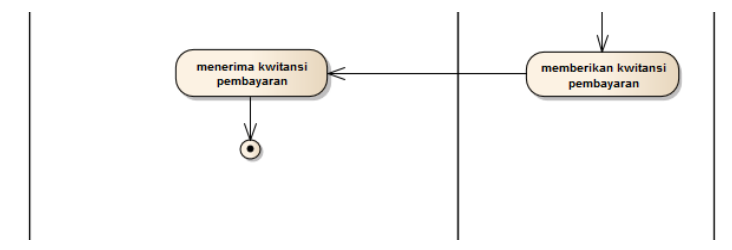

Gambar 2. Activity Diagram Pembayaran Biaya Bimbel

Dengan proses yang ada, maka penulis merancang sebuah alur sistem yang terkomptersasi dimana sistem ini dirancang untuk mempermudah calon siswa untuk melakukan pendaftaran dan juga mempermudah pihak bimbel dalam mengelola datanya.

\subsection{Rancangan Sistem}

a. Tahapan Analisis

Sistem pendaftaran secara online berbasis web dimana bagian adminitrasi dari bimbel tersebut tidak bertemu secara langsung dengan calon siswa yang ingin mendaftar. Calon siswa melakukan proses pendaftarannya melalui media browser. Berikut ini adalah spesifikasi kebutuhan dari sistem pendaftarannya.

Halaman User:

A1. Calon siswa mengisi formulir pendaftaran online.

A2. Siswa dapat login ke ruang siswa.

A3. Siswa dapat melihat jadwal pelajaran online.

A4. Siswa dapat melihat status pembayarannya.

Halaman Admin:

B1. Admin dapat mengelola data siswa.

B2. Admin dapat mengelola data artikel.

B3. Admin dapat mengelola data pendaftaran.

B4. Admin dapat mengelola data pembayaran.

b. Use Case Diagram

Pada bagan Use Case ini penulis akan menjelaskan apasaja yang bisa dilakukan calon siswa saat melakukan pendaftaran melalui sistem informasi ini.

Berikut merupakan bagan Use Case yang ada:

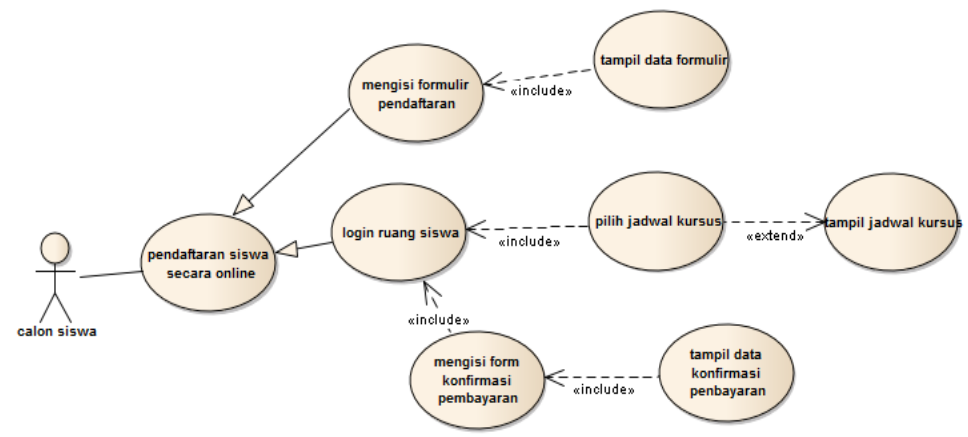

Gambar 3. Use Case Diagram Pendaftaran online Calon Siswa

Dari bagan Use Case diatas, kita bisa melihat saat calon siswa melakukan pendaftaran secara online. Calon siswa bisa melakukan beberapa hal seperti pengisian formulir pendaftaran, login ke ruang siswa, melakukan konfirmasi pembayaran.

c. Activity Diagram

Berikut merupakan rancangan usulan yang penulis buat:

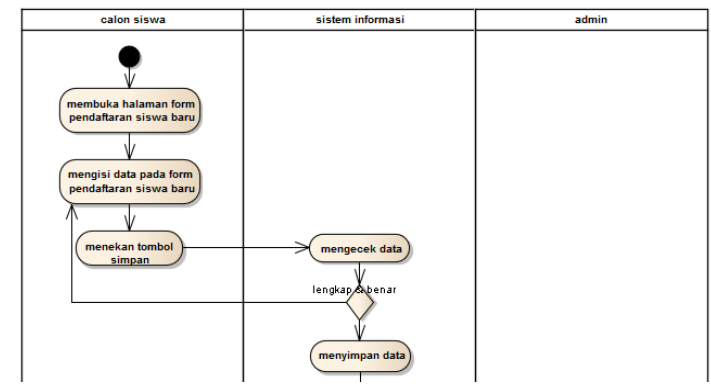




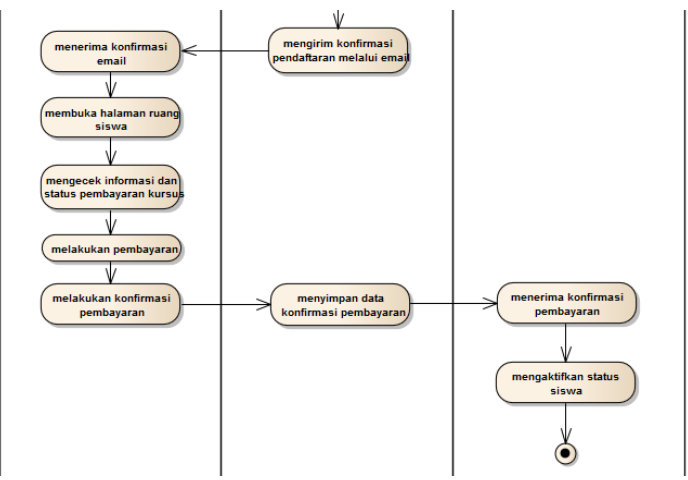

Gambar 4. Activity Diagram Pendaftaran online Calon Siswa

Dari bagan sistem diatas, bisa kita lihat bahwa ada sistem informasi yang menjadi perantara antara calon siswa dan juga admin. Dengan adanta sistem informasi tersebut akan membuat beban pekerjaan dari admin berkurang karena sistem informasi menggantikan beberapa tugas yang harus dikerjakan oleh admin.

Sistem bertugas menyimpan data dan melnampilkannya pada admin. Admin bertugas untuk mengecek kelengkapan dan validasi dari data yang ada. Jika memang sudah sesuai dengan ketentuan, maka admin akan mengaktifkan status siswa.

\section{d. Entity Relationship Diagram (ERD)}

Disini panulis akan memaparkan ERD yang digunakan untuk membuat sistem pendaftaran online yang akan digunakan oleh bimbel tersebut.

Berikut ERD yang telah dibuat oleh penulis

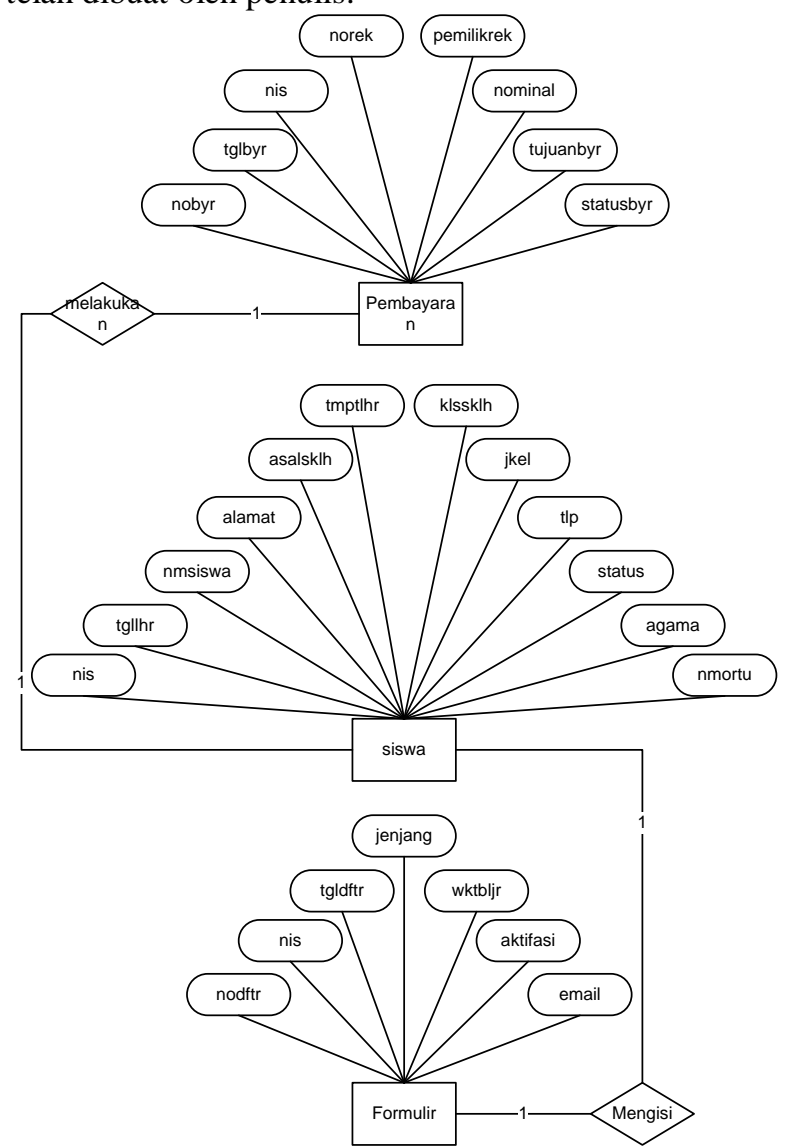

Gambar 5. Entity Relationship Diagram Pendaftaran Calon Siswa

Penulis menggunakan tiga buat entity pada diagram ini yaitu pembayaran, siswa dan formulir. Dimana ketiganya difungsikan sebagai rancangan database yang nantinya difungsikan untuk menyimpan data saat terjadi proses pendaftaran secara online. Data akan disimpan pada masing-masing atribut sesuai dengan nama entity-nya. 
e. Component Diagram

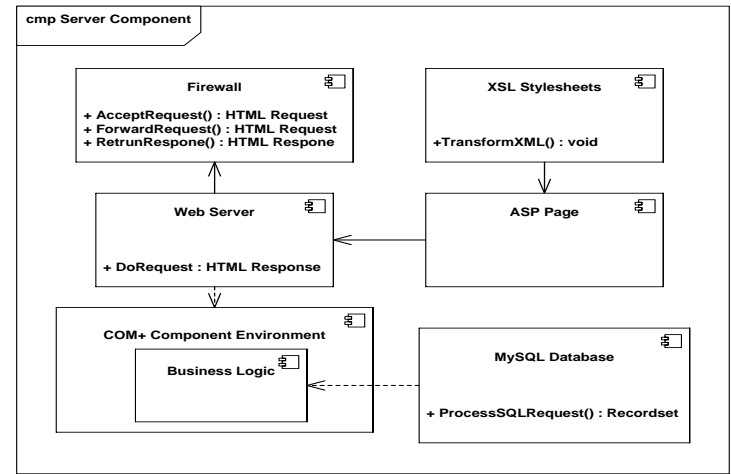

Gambar 6. Component Diagram Sistem Informasi Bimbel Cerdas Ceria

Component Diagram diatas menjelaskan tentang web server yang terdapat component environment didalamnya, ASP page yang dilengkapi oleh XSL stylesheets dan firewall sebagai keamanan. Database Mysql yang memiliki businees logic yang berada didalam component environment.

\section{f. Deployment Diagram}

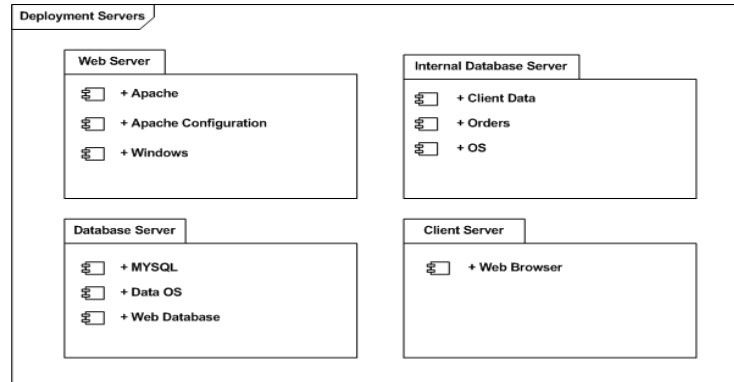

Gambar 7. Deployment Diagram Sistem Informasi Bimbel Cerdas Ceria

Deployment Diagram pada sistem pendaftaran calon siswa seperti Apache yang berjalan pada sistem operasi windows sebagai Web Server, database server berupa MySQL sebagai internal database server dan web browser sebagai Client Server.

g. User Interface

1. Tampilan Beranda

\section{(c2) Cerdas Ceria Beranda Profil Biaya \& Pelajaran Pendaftaran Ruang Siswa Buku Tamu}

\section{Bimbel Cerdas Ceria}

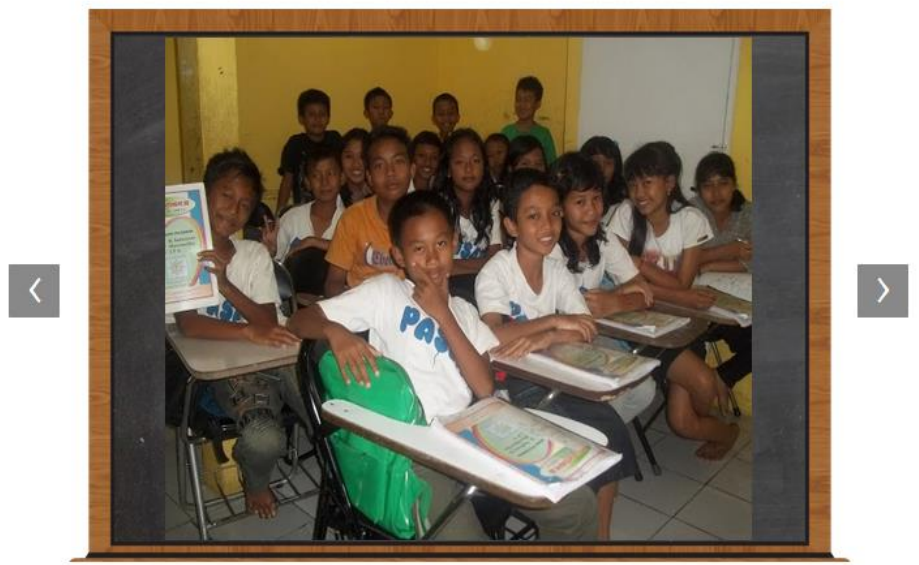

Bimbel Cerdas Ceria merupakan merupakan lembaga pembelajaran yang berkualitas \&

Gambar 8. Tampilan Beranda 
Tampilan beranda diatas merupakan tampilan yang akan muncul pertama kali saat calon siswa membuka aplikasi pendaftaran siswa ini.

2. Tampilan Form Pendaftaran

(C2) Cerdas Ceria Beranda Profil Biaya \& Pelajaran Pendaftaran Ruang Siswa Buku Tamu

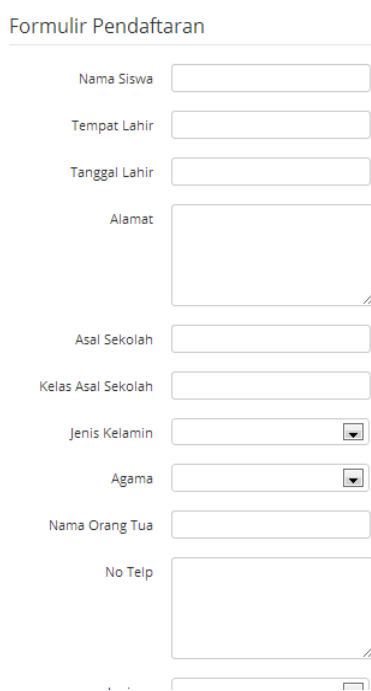

Gambar 9. Tampilan Form Pandaftaran

Tampilan Form pendaftaran diatas merupakan tampilan inputan yang harus calon siswa isi saat melakukan proses pendaftaran.

3. Tampilan Konfirmasi Pembayaran

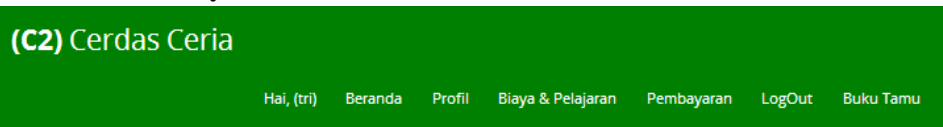

Konfirmasi Pembayaran

Silahkan Di Isi

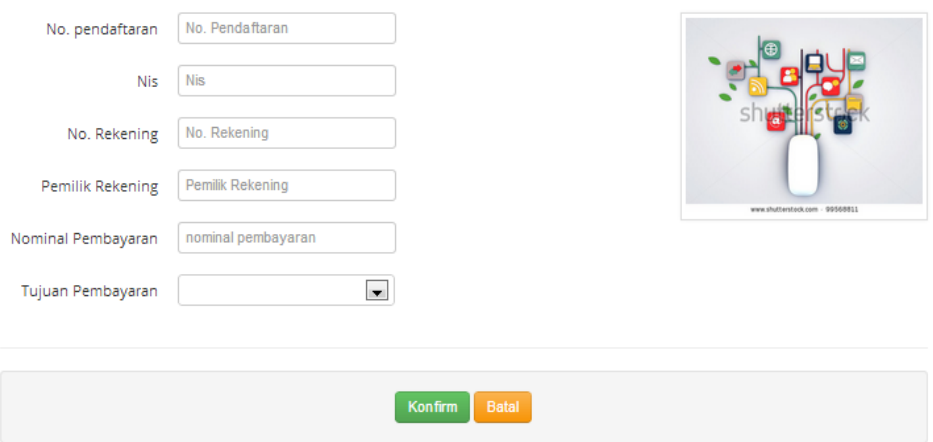

Gambar 10. Tampilan Konfirmasi Pembayaran

Tampilan konfirmasi pembayaran diatas digunakan calon siswa untuk melakukan konfirmasi pembayaran pasca menyelesaikan proses pendaftaran. 
4. Tampilan Login Siswa

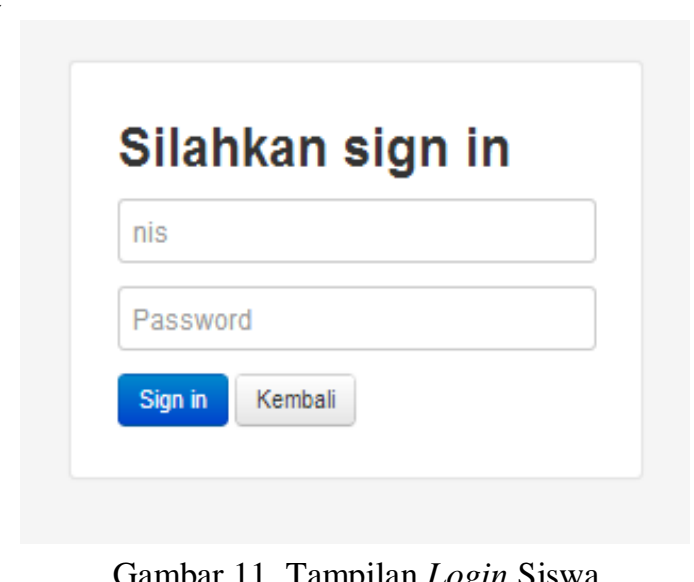

Gambar 11. Tampilan Login Siswa

Tampilan login siswa diatas akan digunakan siswa untuk mengakses informasi tentang proses belajar pada Bimbel Cerdas Ceria.

\section{Conclusion}

Dengan adanya aplikasi web pendaftaran ini, pencarian data siswa menjadi lebih efektif dan efesien. Sehingga tidak membuang banyak waktu. Kehilangan data dapat dihindari seminimal munkin. Hal itu dikarenakan seluruh data disimpan didalam satu database. Sehingga penyebab hilangnya data dikarenakan tempat penyimpanan yang tidak teratur tidak terjadi lagi. Meningkatkan kinerja pada bagian panitia pendaftaran. Penadaftaran siswa dapat dilakukan dimana saja dan kapan saja. Sehingga memudahkan calon siswa yang ingin calon siswa dan meningkatkan persentase pendaftaran bagi pihak bimbel.

\section{References}

[1] Amin, Ruhul.; "RANCANG BANGUN SISTEM INFORMASI PENERIMAAN SISWA BARU PADA SMK BUDHI WARMAN 1 JAKARTA. JURNAL ILMU PENGETAHUAN DAN TEKNOLOGI KOMPUTER”. 2017

[2] Anisah,; Sayuti.; "Perancangan Sistem Informasi Registrasi Online Untuk Penerimaan Siswa Baru Berbasis Web Pada SMK Negeri 1 Kelapa Bangka Barat. Jurnal SISFOKOM". 2018

[3] Nugroho, Adi.; "Rekayasa Perangkat Lunak Berorientasi Objek Dengan Metode USDP”. Yogyakata: ANDI. 2010

[4] Rizky, Soetam.; "Konsep Dasar Rekayasa Perangkat Lunak". Jakarta: Prestasi Pustaka Publsher. 2011

[5] Rosa A.S,; M. Shalahuddin.; "Rekayasa Perangkat Lunak". Bandung: Informatika. 2015

[6] Sarwindah.; "Sistem Pendaftaran Siswa Baru Pada SMP N 1 Kelapa Berbasis Web". Jurnal SISFOKOM. 2018

[7] Suhendar, Cucu.; "RANCANG BANGUN SISTEM INFORMASI PENERIMAAN SISWA BARU BERBASIS WEB (Studi Kasus Pada SMK Ciledug Al-Musaddadiyah Garut)”. Jurnal Algoritma. 2015

[8] Witanto,; Regi.,; \& Solihin, Hanhan Hanafiah.; "PERANCANGAN SISTEM INFORMASI PENERIMAAN SISWA BARU BERBASIS WEB (STUDI KASUS : SMP PLUS BABUSSALAM BANDUNG)”. Jurnal Infotronik. 2016 